\title{
Thyroid and Adrenal Dysfunction in Abstinent Alcoholic Men: Locus of Disturbance
}

Peter T. Loosen, M.D., Ph.D., Bryan Chambliss, Nosa Ekhator, M.S., Donna Burns, R.N., M.S.N., Thomas D. Geracioti, M.D., and David N. Orth, M.D.

Certain neuroendocrine abnormalities (e.g., blunted plasma adrenocorticotropic hormone $[A C T H]$ response to corticotropin-releasing hormone [CRH] administration and blunted serum TSH response to thyrotropin-releasing hormone [TRH] administration) are common in alcoholic patients. It was the objective of this study to evaluate whether they are centrally mediated: that is, whether they are secondary to increased activity of $\mathrm{CRH}$ and/or TRH neurons. We evaluated the nocturnal secretion (2200 hours to 1000 hours, $q 15 \mathrm{~min}$ ) of plasma ACTH, serum cortisol, and serum TSH, and their responses to the combined administration of $C R H$ and TRH, in 28 acutely abstinent alcoholic (age range: 32 to 57 years; mean: 42.4 years) and 19 normal men (age range: 21 to 52 years; mean: 32.1 years). To assess the validity of administering $C R H$ and TRH simultaneously, we gave 10 additional abstinent alcoholic men (age range: 36 to 53 years; mean: 45.8 years), in random order and at least 4 days apart, either $C R H, T R H$, placebo, or $C R H$ plus TRH. Nocturnal ACTH, cortisol, and TSH secretion, as well as cortisol and TSH responses after CRH plus TRH administration, were similar in alcoholic and normal men. However, ACTH peak responses to CRH plus TRH were reduced in the alcoholic men ( $\mathrm{p}<$ 0.05). The ACTH, but not cortisol, response was greater after combined $C R H$ plus TRH administration than after CRH alone $(\mathrm{p}<.002)$. The blunted ACTH response does not appear to be the result of increased endogenous $C R H$ activity, because all parameters of nocturnal ACTH pulsatility were normal in the alcoholics. It rather appears to be secondary to an intrinsic defect in the $\mathrm{CRH}$ responsiveness of the pituitary corticotroph, possibly due to genetic vulnerability or to the toxic effects of prolonged alcohol abuse. [Neuropsychopharmacology 9:255-266, 1993]
KEY WORDS: TRH, CRH, Thyroid hormones, Adrenal hormones, Alcoholism, Abstinence

Chronic alcoholism is often associated with pseudoCushing's syndrome (Smals et al. 1976; Rees et al. 1977;

From the Departments of Psychiatry (PTL, BC, NE, TDG) and Medicine (PTL, DNO) Vanderbilt University Medical Center; and Department of Veterans Affairs Medical Center (PTL, NE, DB, TDG) Nashville, Tennessee.

Address correspondence to: Peter T. Loosen, M.D., Ph.D., Chief, Psychiatry Service (116A), Department of Veterans Affairs Medical Center, 1310 24th Avenue South, Nashville, TN 37212-2637.

Received September 30, 1992; revised July 13, 1993; accepted July 19, 1993. van Thiel et al. 1983; Marks and Wright 1977) and euthyroid sick syndrome (Loosen et al. 1979, 1983, 1992). There are abnormalities in hypothalamic-pituitary-adrenal (HPA) and hypothalamic-pituitary-thyroid (HPT) axes function that characterize these syndromes, such as, increased plasma cortisol concentration (Valimaki et al. 1984; Risher-Flowers et al. 1988; Mendelson and Stein 1966), resistance of plasma cortisol to suppression by dexamethasone (Swartz and Dunner 1984; Targum 1984), blunted plasma adrenocorticotropic hormone (ACTH) response to corticotropin-releasing hormone (CRH) administration (Adinoff et al. 1990; von Bardeleben et al. 1989; Heuser et al. 1988; Loosen et al. 1991), and blunted serum TSH response to thyrotropin-releas- 
ing hormone (TRH) administration (Loosen et al. 1979, 1983, 1992; Loosen 1988).

It has been postulated that these functional alterations in the HPA and HPT axes are centrally mediated; that is, they are secondary to increased activity of $\mathrm{CRH}$ and/or TRH neurons, resulting in downregulation of CRH and TRH receptors (Loosen 1988; Adinoff et al. 1990; von Bardeleben et al. 1989; Loosen et al. 1991, 1992; Holsboer et al. 1987). In support of this concept, Mortola et al. (1987) demonstrated that the hypercortisolemia in women with major depressive disorder was associated with increased ACTH pulse frequency, expanded cortisol secretory episodes, and a shortened evening quiescent period of cortisol secretion, suggesting a centrally mediated HPA axis activation. To test this hypothesis in alcoholic patients, we studied the nocturnal secretory patterns of immunoreactive plasma $\mathrm{ACTH}$, serum cortisol, and serum TSH and their responses to CRH and TRH. Hypothesizing that increased release of $\mathrm{CRH}$ and TRH is associated with increased activity of the endogenous pulse generator(s), we utilized a computer-assisted pulse-analysis program (CLUSTER) to determine the parameters of nocturnal hormonal pulsatility.

\section{SUBJECTS AND METHODS}

\section{Subjects}

Twenty eight alcoholic men, aged 32 to 57 years (42.4 \pm 7.6 years, mean $\pm S D$ ), were recruited from the Nashville Veterans Administration Chemical Dependency Treatment Program (VA-CDTP) and studied after they had given their informed consent. All had drunk heavily, leading to multiple alcohol-related hospital admissions. At the time of study, they were abstinent from alcohol for 15 days to 110 days (Table 1 ) and were taking no psychotropic medication. Abstinence was assured by participation in the inpatient VA-CDTP. Nineteen normal volunteer men, aged 21 to 52 years (32.1 \pm 6.2 years) were also studied. Diagnoses were made according to the research diagnostic criteria (RDC)(Spitzer et al. 1978), the Diagnostic and Statistical Manual of Mental Disorders (DSMIII-R), and the Michigan Alcoholism Screening Test (Selzer 1971); all alcoholic patients met RDC requirements for definite alcoholism and DSMIII-R criteria for alcohol dependence. Twentysix of the alcoholic men also fulfilled criteria for type 2 alcoholism according to Cloninger (1987), with onset of drinking before age 25 , development of spontaneous alcohol-seeking behavior or inability to abstain, frequent fighting and arrests when drinking, infrequent psychological dependence with loss of control, infrequent guilt and fear about alcohol dependence, and the triad (characteristic for antisocial personality disorders) of high novelty seeking, low harm avoidance, and low
Table 1. Clinical Characteristics of the Abstinent Alcoholic Men

\begin{tabular}{|c|c|c|c|c|c|}
\hline \multirow[b]{2}{*}{ Subjects } & \multirow[b]{2}{*}{$\begin{array}{l}\text { Age } \\
\text { (yrs) }\end{array}$} & \multicolumn{4}{|c|}{ Alcoholism } \\
\hline & & $\begin{array}{l}\text { Psych. }^{a} \\
\text { History }\end{array}$ & $\begin{array}{c}\text { History } \\
\text { (yrs) }\end{array}$ & $\begin{array}{c}\text { MAST }^{\mathbf{b}} \\
\text { (score) }\end{array}$ & $\begin{array}{c}\text { Abstinence } \\
\text { (days) }\end{array}$ \\
\hline 1 & 35 & MDD, PD & 21 & 30 & 39 \\
\hline 2 & 56 & - & 40 & 10 & 16 \\
\hline 3 & 35 & - & 25 & 29 & 23 \\
\hline 4 & 32 & - & 16 & 29 & 21 \\
\hline 5 & 57 & - & 4 & 29 & 19 \\
\hline 6 & 36 & - & 8 & 23 & 21 \\
\hline 7 & 48 & - & 33 & 25 & 22 \\
\hline 8 & 42 & - & 25 & 26 & 20 \\
\hline 9 & 41 & - & 20 & 29 & 15 \\
\hline 10 & 35 & - & 20 & 14 & 29 \\
\hline 11 & 37 & MDD & 28 & 29 & 90 \\
\hline 12 & 33 & - & 17 & 17 & 53 \\
\hline 13 & 46 & MDD & 30 & 24 & 34 \\
\hline 14 & 36 & MDD, PDA & 21 & 12 & 49 \\
\hline 15 & 57 & - & 30 & 24 & 110 \\
\hline 16 & 45 & PDA & 30 & 29 & 37 \\
\hline 17 & 44 & PDA & 28 & 27 & 36 \\
\hline 18 & 50 & MDD, PD & 30 & 27 & 30 \\
\hline 19 & 32 & MDD, PDA & 10 & 27 & 32 \\
\hline 20 & 40 & PDA & 20 & 27 & 69 \\
\hline 21 & 43 & - & 28 & 12 & 33 \\
\hline 22 & 52 & MDD & 30 & 27 & 61 \\
\hline 23 & 36 & MDD, PDA & 21 & 27 & 60 \\
\hline 24 & 45 & MDD, PDA & 29 & 29 & 30 \\
\hline 25 & 39 & PDA & 21 & 29 & 45 \\
\hline 26 & 48 & - & 32 & 29 & 60 \\
\hline 27 & 49 & MDD & 31 & 29 & 107 \\
\hline 28 & 38 & PDA & 20 & 27 & 39 \\
\hline Mean & 42.4 & - & 23.3 & 24.8 & 42.9 \\
\hline$\pm \mathrm{SD}$ & 7.6 & & 8.1 & 5.9 & 25.7 \\
\hline
\end{tabular}

${ }^{a}$ Past psychiatric disorders: MDD, major depressive disorder; $\mathrm{PD}$, panic disorder; PDA, polydrug abuse (i.e., alcoholism plus cannabis, cocaine, or opiate dependence).

b The Michigan Alcoholism Screening Test (Selzer 1971).

reward dependence. Two patients were classified as type 1 alcoholics. Medical illness was excluded by normal history, physical examination, and routine screening laboratory tests. A complete liver profile was also obtained immediately before study entry (Table 2). Seven alcoholic men had gamma-glutamyltransferase elevations (Table 2) consistent with the long-standing nature and severity of their alcoholism (Table 1). None of the alcoholic or normal men was clinically depressed at the time of testing, as assessed by clinical interview and the Hamilton Depression Rating Scale (Hamilton 1960); the score (items 1 to 17) was less than 8 in all men. An additional 10 alcoholic men, aged 36 to 53 years ( 45.8 \pm 6.4 years), were also studied to validate administering CRH plus TRH simultaneously. They received, in random order and at least 4 days apart, either $\mathrm{CRH}$, TRH, placebo, or CRH plus TRH. 
Table 2. Liver Profiles of Abstinent Alcoholic Men

\begin{tabular}{|c|c|c|c|c|c|c|}
\hline Subjects & Albumin ${ }^{a}$ & $\mathbf{L D H}^{\mathbf{b}}$ & $\begin{array}{c}\text { Alkaline } \\
\text { Phosphatase }^{c}\end{array}$ & $\begin{array}{c}\text { Total } \\
\text { Protein }\end{array}$ & AST $^{\mathbf{e}}$ & $y-G^{f}$ \\
\hline 1 & 4.1 & 82 & 12 & 6.2 & 12 & 9 \\
\hline 2 & 3.8 & 115 & 16 & 6.8 & 13 & 22 \\
\hline 3 & 4.2 & 105 & 12 & 6.9 & 8 & 13 \\
\hline 4 & 3.9 & 88 & 10 & 6.0 & 12 & 8 \\
\hline 5 & 4.1 & 91 & 10 & 6.6 & 17 & 24 \\
\hline 6 & 4.3 & 106 & 7 & 6.7 & 13 & 28 \\
\hline 7 & 3.9 & 98 & 9 & 6.7 & 26 & $71^{\star}$ \\
\hline 8 & 4.1 & 42 & 16 & 6.4 & 12 & 15 \\
\hline 9 & 4.1 & 113 & 7 & 7.1 & 14 & 34 \\
\hline 10 & 4.3 & 104 & 6 & 7.2 & 12 & 32 \\
\hline 11 & 4.3 & 135 & 5 & 6.9 & 15 & 6 \\
\hline 12 & 4.4 & 95 & 9 & 7.0 & 10 & 10 \\
\hline 13 & 4.0 & 91 & 9 & 6.2 & 8 & 6 \\
\hline 14 & 3.9 & 113 & 9 & 6.7 & 9 & 12 \\
\hline 15 & 4.0 & 66 & 11 & 6.5 & 9 & $43^{\star}$ \\
\hline 16 & 4.3 & 121 & 6 & 7.1 & 14 & 15 \\
\hline 17 & 3.9 & 236 & - & 7.8 & 23 & 5 \\
\hline 18 & 4.7 & 112 & 10 & 7.7 & 57 & $60^{\star}$ \\
\hline 19 & 4.6 & 129 & 64 & 8.1 & 27 & 23 \\
\hline 20 & 4.2 & 106 & 10 & 6.8 & 16 & 19 \\
\hline 21 & 4.0 & 116 & 6 & 6.8 & 7 & 4 \\
\hline 22 & 3.9 & 145 & 6 & 6.5 & 18 & 6 \\
\hline 23 & 4.4 & 93 & 10 & 7.0 & 19 & $41^{\star}$ \\
\hline 24 & 4.5 & 93 & 9 & 7.0 & 20 & $77^{\star}$ \\
\hline 25 & 4.1 & 103 & 9 & 6.7 & 12 & 37 \\
\hline 26 & 4.4 & 84 & 11 & 7.1 & 8 & $41^{\star}$ \\
\hline 27 & 4.3 & 138 & 6 & 7.5 & 11 & 19 \\
\hline 28 & 4.1 & 127 & 11 & 7.1 & 56 & $72^{\star}$ \\
\hline Mean & 4.2 & 109 & 11.3 & 6.9 & 17.1 & 26.9 \\
\hline$\pm \mathrm{SD}$ & 0.2 & 33 & 10.9 & 0.5 & 12.3 & 21.6 \\
\hline
\end{tabular}

a Normal range: 3.5 to $5.0 \mathrm{gr} / \mathrm{dL}$.

b Normal range: 125 to $250 \mathrm{IU} / \mathrm{L}$.

c Normal range: 2 to 40 IU/L.

d Normal range: 6 to $8 \mathrm{gr} / \mathrm{dL}$.

e Aspartate aminotransferase $=$ SGOT (normal range: 4 to $40 \mathrm{IU} / \mathrm{L}$ ).

${ }^{f} \gamma$-glutamyltransferase (normal range: 2 to $40 \mathrm{IU} / \mathrm{L}$ ).

\section{Hormone Testing}

The alcoholic and normal men were admitted to the General Clinical Research Center (GCRC) of Vanderbilt University Medical Center for 2 days. A standardized activity schedule was maintained with meals at 0800 hours, 1200 hours, and 1700 hours, and lights out at 2300 hours. Meals contained approximately $50 \%$ carbohydrate, $35 \%$ fat, and $15 \%$ protein. Ambulation and daytime napping were minimized.

Nocturnal Hormone Secretion. At 2000 hours on the frrst day an intravenous line was inserted, and, beginning at 2200 hours, blood samples were drawn every 15 minutes for 12 hours.

Releasing Hormone Administration. At 1600 hours the following day, synthetic ovine $\mathrm{CRH}(1 \mu \mathrm{g} / \mathrm{kg})$ and TRH $(200 \mu \mathrm{g})$ were administered as sequential 20 -second infusions, at least 1 hour after an intravenous heparin lock was placed in a forearm vein (Sheldon et al. 1985). Blood samples were withdrawn 15 minutes before, just prior to, and 5, 10, 15, 30, 45, 60, 90, and 120 minutes after the infusion.

Separate Administration of CRH, TRH, CRH plus TRH, and Placebo. The validity of simultaneously administering CRH plus TRH has been demonstrated in normal subjects (Sheldon et al. 1985; Cohen et al. 1986; Holl et al. 1988; Schopohl et al. 1986) but not in alcoholic subjects. Therefore, we studied 10 additional alcoholic men, using the same study design for peptide dosage and time of administration. Each patient received, in random order and at least 4 days apart, $\mathrm{CRH}$ alone, TRH alone, CRH plus TRH, or placebo.

\section{Hormone Assays}

Ethylenediaminetetraacetic acid plasma and serum were prepared and stored at $-70^{\circ} \mathrm{C}$ for later assay. 
Plasma ACTH and serum cortisol and TSH were measured by radioimmunoassay. The assay for plasma ACTH employed rabbit anticorticotropin serum IgGACTH-1 (IgG Corp., Nashville, TN), which is directed at the bioactive ACTH-(5-18) sequence. Synthetic human ACTH (Ciba-Geigy, Basle, Switzerland) was used as ${ }^{125}$ I-labeled tracer and as reference standard. Phase separation was achieved by the addition of goat anti-rabbit IgG. Sensitivity of the ACTH assay was 1.1 to $2.2 \mathrm{pmol} / \mathrm{L}$. Serum TSH, free thyroxine (FT4), and total triiodothyronine (QT3) concentrations were measured with commercially available kits. All radioimmunoassay methods have previously been described(Sheldon et al. 1985). All hormone concentrations are given in Sl units (Lundberg et al. 1986).

\section{Pulse Analysis}

A computer-assisted pulse-analysis program (CLUSTER) was used to evaluate pulse frequency and amplitude, interpulse interval, and area-under-the-curve of nocturnal hormone secretion. Significant pulses were detected with Veldhuis et al.'s modification (Veldhuis et al. 1984; Urban et al. 1989) of the method of Santen and Bardin (1973), which requires that a significant pulse exhibit a nadir-to-peak difference of at least four times the intraassay coefficient of variation at the level of the nadir. The intraassay coefficient of variation for any one subject was computed from 30 to 90 assay replicates of a serum pool derived from that individual's samples and run in the same assay. For TSH and cortisol, nadir and peak sizes of 1 were used, with a $t$-statistic of 2.0 for both upstroke and downstroke, whereas for ACTH a nadir size of 2 and a peak size of 1 were used, with a $t$-value of 2.0 for both upstroke and downstroke (J. Veldhuis, personal communication). For all hormones, a power function was used to estimate variance.

To evaluate possible associations between alterations in the basal nocturnal rhythm and the pattern of response to $\mathrm{CRH}$ plus TRH administration, we correlated the plasma ACTH, serum cortisol, and serum TSH response increments to the releasing hormones with their peak pulse frequency and peak pulse amplitude.

\section{Statistical Analysis}

Nocturnal and response data across groups were analyzed by repeated-measures analysis of variance (ANOVA) (Winer 1976). For the nocturnal hormonelevels, group (control vs. alcoholic) was a between-subjects factor, and time was a within-subjects factor. For the hormone response test, a similar design was used except that the levels for the time factor were baseline versus peak values. Results from the CLUSTER analy- sis were analyzed using a one-way ANOVA, with group as a between-subjects factor. Pearson's Product Moment Correlation was used for the correlation analyses of nocturnal and response data. For all analyses, an alpha level of 0.01 was used to control for the number of hormones (five) being analyzed.

\section{RESULTS}

\section{Nocturnal Hormonal Secretion}

Plasma ACTH(Fig. 1) and serum cortisol concentrations increased significantly $(p<.0001)$ during the night in both alcoholic and normal men; there were no intergroup or time-by-group interactions. The CLUSTER analysis showed that the pulse frequency and amplitude of ACTH, cortisol, and TSH secretion were similar in alcoholic and normal men (Table 3).

\section{Responses to CRH plus TRH Administration}

The increment (peak minus baseline) and area-underthe-curve above baseline were calculated for plasma ACTH, serum cortisol, and serum TSH. There were no significant differences in cortisol or TSH responses been alcoholic and normal men (Table 4). In contrast, repeated-measures ANOVA revealed a significant timeby-group effect for $\mathrm{ACTH}(F=4.32 ; d f=1,45 ; p=.045)$ (Table 4). Although ACTH responses to CRH were reduced in the alcoholic men, the resulting plasma $\mathrm{ACTH}$ concentrations stimulated normal serum cortisol concentrations (Fig. 2).

\section{Correlation Between Nocturnal Secretion and Response to Releasing Hormones}

There was no significant correlation between the increment in plasma/serum hormone concentration after $\mathrm{CRH}$ plus TRH administration and either nocturnal peak frequency or nocturnal peak amplitude.

\section{Separate Administration of CRH, TRH, CRH plus TRH, and Placebo}

The responses of serum cortisol and TSH were unaffected by the combined administration of $\mathrm{CRH}$ plus TRH. However, the ACTH response was greater after CRH plus TRH than after $\mathrm{CRH}$ alone $(F=19.12 ; d f=$ 1,$9 ; p<.002$ ) (Fig. 3).

\section{DISCUSSION}

\section{Adrenal Hormones}

Under basal conditions, the HPA axis is most active at approximately the time of awakening. Thereafter, 

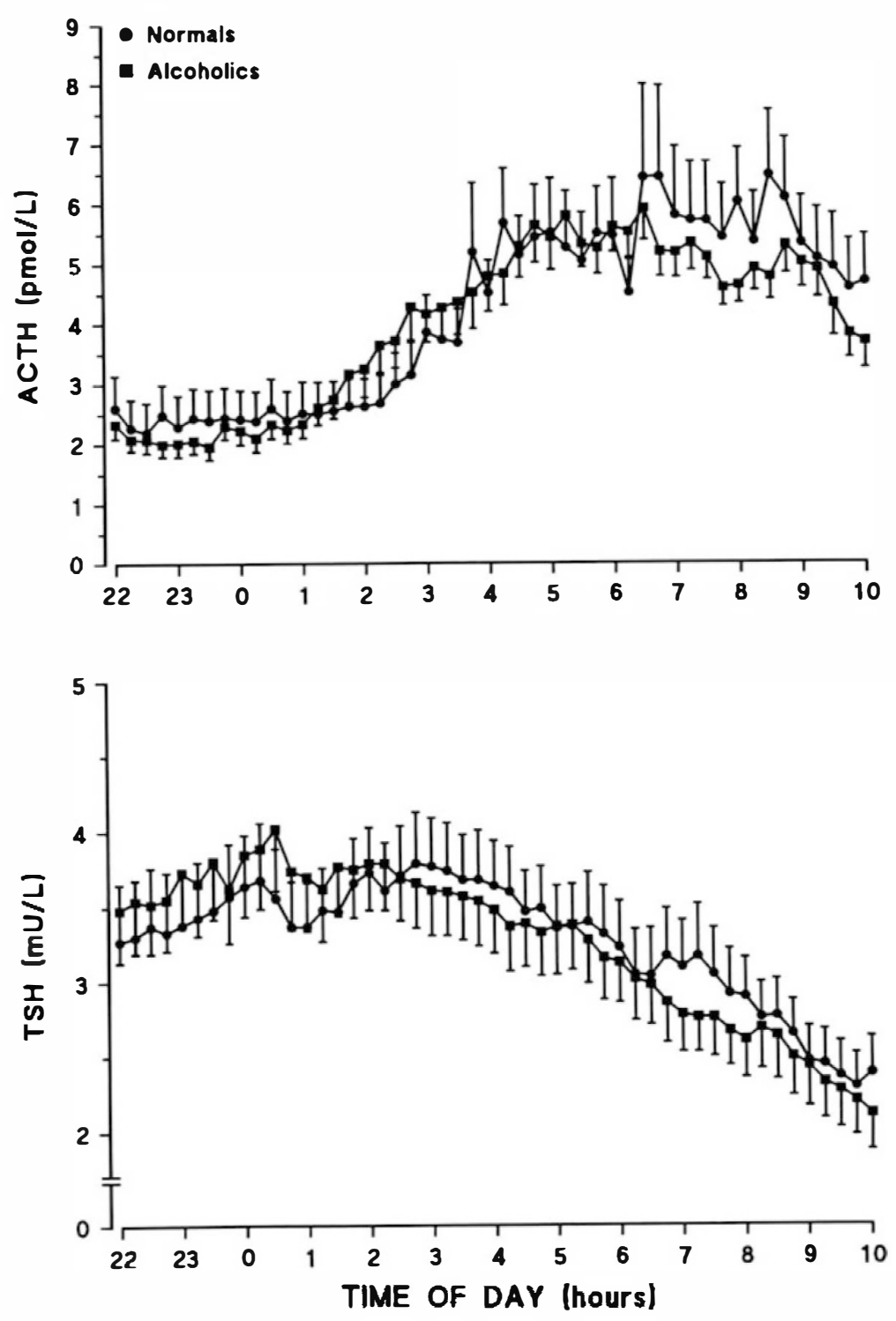

Figure 1. Nocturnal secretion of plasma ACTH and serum TSH in 28 alcoholic and 19 normal men.

Table 3. CLUSTER Analysis of the Nocturnal Hormonal Concentrations in 28 Abstinent Alcoholic and 19 Normal Men

\begin{tabular}{lccc}
\hline Hormones & Peaks/12 Hours & Peak Amplitude (\%) & $\boldsymbol{p}^{\mathbf{a}}$ \\
\hline ACTH (pmol/L): & & & \\
$\quad$ Alcoholics & $4.6 \pm 1.2$ & $217 \pm 52$ & NS $^{\mathrm{b}}$ \\
$\quad$ Controls & $4.1 \pm 1.2$ & $293 \pm 227$ & \\
Cortisol (nmol/L): & $5.2 \pm 1.8$ & $342 \pm 142$ & $\mathrm{NS}$ \\
$\quad$ Alcoholics & $5.7 \pm 1.8$ & $338 \pm 152$ & \\
$\quad$ Controls & $4.1 \pm 2.0$ & $131 \pm 16$ & $\mathrm{NS}$ \\
TSH (mU/L): & $3.3 \pm 1.8$ & $134 \pm 15$ & \\
$\quad$ Alcoholics & & & \\
Controls & & &
\end{tabular}

a Repeated-Measures ANOVA.

b Alcoholics not significantly different $(p<.05)$ from controls.

Data are presented as means \pm SD. 
Table 4. Hormonal Responses After CRH/TRH Administration in 28 Abstinent Alcoholic and 19 Normal Men

\begin{tabular}{lcrrr}
\hline Hormones & Baseline & \multicolumn{1}{c}{ Peak } & AUC & $p^{\mathbf{a}}$ \\
\hline ACTH (pmol/L): & & & & \\
$\quad$ Alcoholics & $3.3 \pm 1.7$ & $9.9 \pm 4.4$ & $814 \pm 338$ & $<0.0001^{\mathrm{b}}$ \\
$\quad$ Controls & $4.1 \pm 3.0$ & $13.7 \pm 7.4$ & $1046 \pm 529$ & $<0.05^{\mathrm{c}}$ \\
Cortisol (nmol/L): & & & & \\
$\quad$ Alcoholics & $230 \pm 98$ & $590 \pm 128$ & $59,450 \pm 10,910$ & $<0.0001^{\mathrm{b}}$ \\
$\quad$ Controls & $208 \pm 83$ & $618 \pm 168$ & $59,230 \pm 14,250$ & \\
TSH (mU/L): & & & & \\
$\quad$ Alcoholics & $2.4 \pm 1.7$ & $23.7 \pm 9.6$ & $1839 \pm 760$ & $<0.0001^{\mathrm{b}}$ \\
$\quad$ Controls & $2.3 \pm 1.0$ & $20.5 \pm 7.7$ & $1676 \pm 717$ & \\
\hline
\end{tabular}

${ }^{a}$ Repeated-measures ANOVA.

${ }^{b}$ Increment (peak minus baseline) in hormone concentration for both alcoholics and controls.

' Alcoholic versus control increment in hormone concentration.

Data are presented as means $\pm \mathrm{SD}$.

Figure 2. Responses of plasma ACTH and serum cortisol to $\mathrm{CRH}$ administration in 28 alcoholic and 19 normal men. Repeatedmeasures ANOVA revealed significant time $\times$ group effects for $\mathrm{ACTH}(F=4.32, d f=1,45$; $p=.045)$.
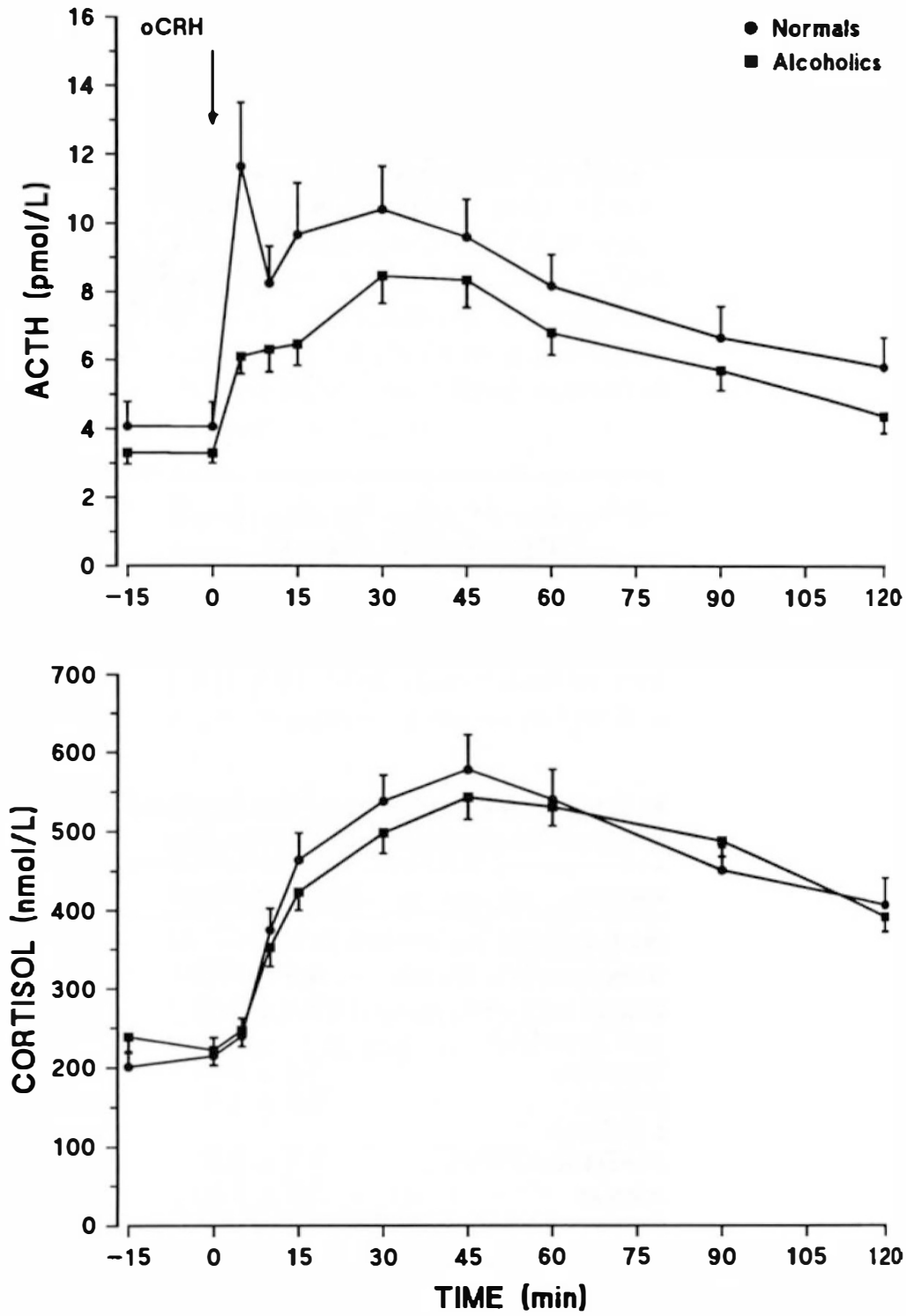

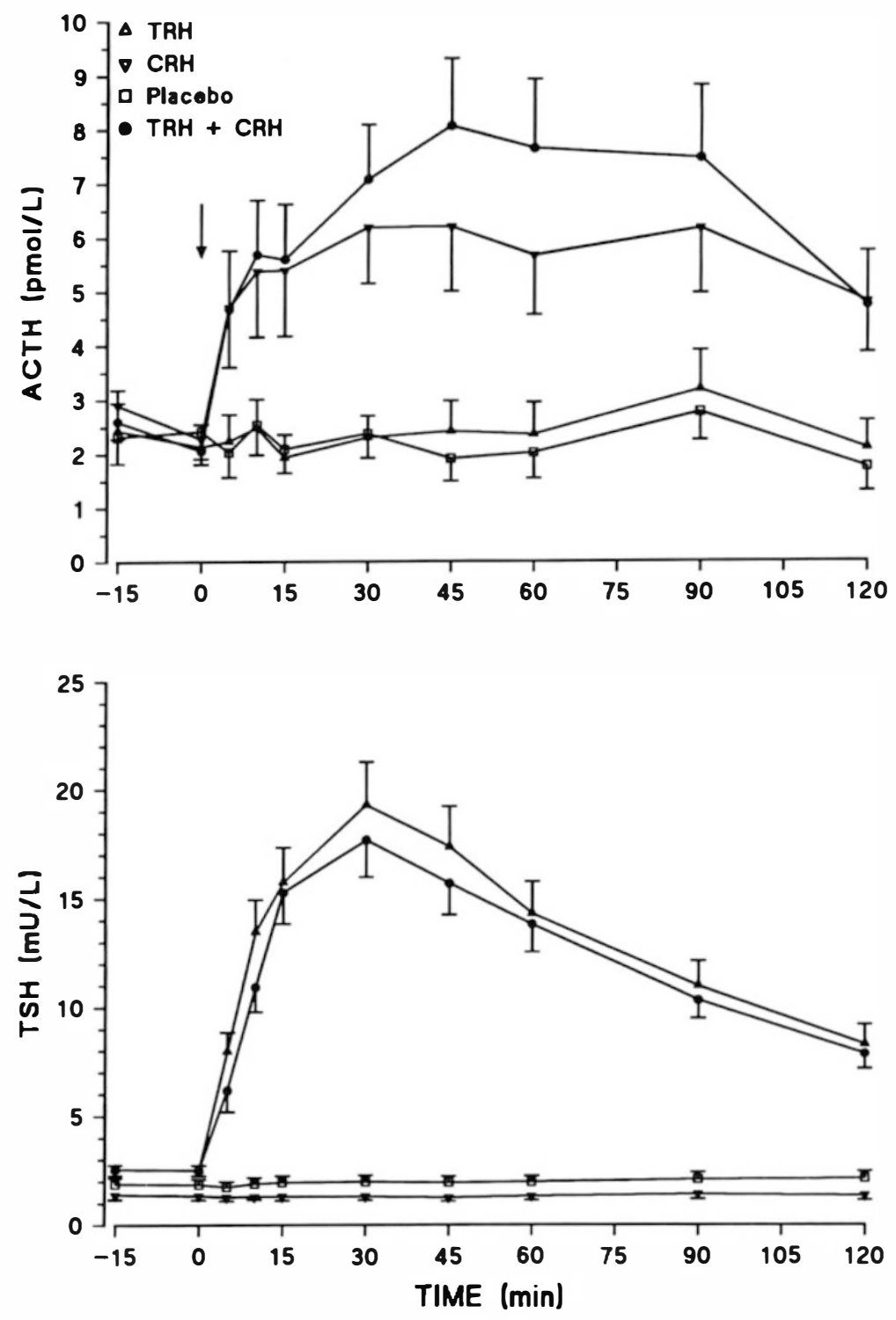

Figure 3. Responses of plasma ACTH and serum TSH to the separate administration of TRH, $\mathrm{CRH}$, placebo, and TRH plus $\mathrm{CRH}$ in 10 alcoholic men. Repeated-measures ANOVA revealed that the $A C T H$ response was greater after $\mathrm{CRH}$ plus TRH than after CRH alone $(F=19.12 ; d f=1,9$; $p<.002)$.

plasma ACTH and serum cortisol concentrations progressively decrease to reach nadirs during the early hours of sleep (Little 1981). Our results indicate that nocturnal secretion of ACTH and cortisol is normal in abstinent alcoholic men: mean hormone concentration, as well as peak frequency, peak amplitude, and total area-under-the-curve were similar in alcoholic and normal men. This finding is consistent with most previous reports. In a study of the acute and chronic effects of alcohol in normal volunteers, Prinz et al. (1980) reported no change in nocturnal plasma cortisol concentrations, as did Bertello et al. (1982) in alcoholic men with hypogonadal features. Rosman et al. (1982) noted normal mean 24-hour total and free-plasma cortisol concentrations and normal circadian rhythmicity, but decreased circadian amplitude and fewer cortisol secretory peaks in patients with alcoholic liver disease. In contrast, Iranmanesh et al. (1989) reported elevated mean and total integrated 24-hour serum cortisol concentration, normal cortisol pulse frequency, increased circadian amplitude, and delay of the circadian peak during acute abstinence; sustained abstinence was associated with decreased mean maximal peak amplitude and mean 24-hour concentrations of serum cortisol. Nocturnal ACTH secretion has not previously been studied.

Like other investigators, we noted significantly attenuated plasma ACTH responses to CRH in the alcoholic men that were, nevertheless, apparently sufficient to stimulate normal serum cortisol responses. This presumably reflected the fact that the plasma ACTH concentrations were acutely near-maximally stimulating for the adrenal cortex. Alternatively, it could reflect increased adrenocortical sensitivity to ACTH in alcoholic 
patients. Berman et al. (1990) reported blunted ACTH but normal cortisol responses after insulin-induced hypoglycemia in actively drinking alcoholic patients. Adinoff et al. (1990) demonstrated significantly attenuated ACTH but normal cortisol responses in alcoholics at both 1 and 3 weeks of abstinence. Von Bardeleben et al. (1989) reported blunted ACTH responses in alcoholic patients during acute withdrawal and after 2 to 6 weeks and 2 to 6 months of abstinence. The data suggest that the blunted ACTH response to CRH remains stable over time and, consequently, that acute alcohol intake and/or withdrawalphenomena are unlikely contributors to the ACTH blunting. Between $19 \%$ and $39 \%$ of nondepressed alcoholic patients show resistance to dexamethasone suppression during alcohol withdrawal; this rate drops to $6 \%$ to $18 \%$ after approximately 3 weeks of abstinence (Khan et al. 1984; Evans and Golden 1987). It is unclear why the blunted ACTH response to CRH in abstinent alcoholic patients persists over time, whereas resistance to dexamethasone suppression does not.

In an additional 10 alcoholic men whom we studied, the ACTH response after CRH plus TRH administration was significantly greater than after $\mathrm{CRH}$ alone. Although the pathophysiology of this finding remains to be determined, the data suggest that the combined use of TRH and CRH may produce some false positive ACTH responses, making the $\mathrm{ACTH}$ responses to $\mathrm{CRH}$ of our alcoholic patients appear less blunted than was actually the case. Previous studies in normal healthy volunteers had shown that ACTH after the combined administration of $\mathrm{CRH}$ plus TRH was comparable to that after separate administration (Sheldon et al. 1985; Cohen et al. 1986; Holl et al. 1988; Schopohl et al. 1986).

Blunted ACTH responses to CRH are not specific for alcoholism. They havealso been observed in patients with anorexia nervosa (Gold et al. 1986a; Hotta et al. 1986), panic disorder (Roy Byrne et al. 1986), major depression (Gold et al. 1986b; Lesch et al. 1989; Kathol et al. 1989; Amsterdam et al. 1988; Holsboer et al. 1984), and posttraumatic stress disorder (Smith et al. 1989). However, in each of these conditions, ACTH blunting is usually associated with demonstrable hypercortisolemia, whereas the alcoholic patients reported here had normal basal serum cortisol levels. It is possible that their total daily cortisol secretion may have been increased, but this was not reflected in serum cortisol concentrations during the observation period.

It has been postulated that the blunted ACTH response to CRH in depression (Gold et al. 1986b; Lesch et al. 1989; Kathol et al. 1989; Amsterdam et al. 1988; Holsboer et al. 1984) and alcoholism (Holsboer et al. 1987) are the result of hypothalamic dysfunction, that is, increased activity of CRH neurons. In support of this concept, Mortola et al. (1987) demonstrated that the hypercortisolemia in women with major depressive disorder was associated with increased ACTH pulse fre- quency, expanded cortisol secretory episodes, and a shortened evening quiescent period of cortisol secretion, suggesting a centrally mediated HPA axis activation. However, the blunted ACTH response in depression may be a direct effect of basal hypercortisolemia, because acutely lowering cortisol secretion by metyrapone administration restores $\mathrm{ACTH}$ responses to $\mathrm{CRH}$ to normal (von Bardeleben et al. 1988). In our alcoholic patients, nocturnal ACTH pulse frequency and amplitude were normal, suggesting that the blunted $\mathrm{ACTH}$ response to $\mathrm{CRH}$ was not due to increased secretion of endogenous $\mathrm{CRH}$.

Adinoff et al. (1990) have suggested that the blunted ACTH response in alcoholic patients reflects an intrinsic defect in the pituitary corticotroph's response to $\mathrm{CRH}$, possibly due to genetic vulnerability or to the toxic effects of prolonged alcohol abuse. Our results are consistent with this hypothesis or with an effect of brief abstinence from alcoholism, but they provide no further insights into etiology, pathophysiology, or (in the case of toxicity) persistence over time.

The finding of blunted ACTH responses in abstinent alcoholics suggests that the abnormality may be a trait marker, at least in some patients. Although the psychiatric manifestations of chronic alcohol abuse usually return to normal after a short period of abstinence, other changes, including neuroendocrine reactivity (Loosen et al. 1983, 1991; Adinoff et al. 1990; von Bardeleben et al. 1989; Heuser et al. 1988), event-related brain potentials (Begleiter et al. 1981), and cognitive behavior (Tarter and Edwards 1985; Eckardt and Ryback 1981) may remain impaired for several months to years after abstinence and may even be seen in the nonalcoholic sons of alcoholic patients (Begleiter et al. 1984; Tarter et al. 1984). Moreover, Schuckit et al. (1987a, 1987b, 1988) demonstrated in a series of elegant experiments that sons of alcoholic fathers had lower levels of ACTH, cortisol, and prolactin following an ethanol challenge, suggesting that these neuroendocrine abnormalities may be part of a genetic predisposition toward alcoholism. A more detailed analysis of both alcoholic patients (studied at various times during abstinence from alcoholism) and sons of alcoholics is necessary to document whether blunted $\mathrm{ACTH}$ response to $\mathrm{CRH}$ can be added to the increasing list of abnormalities seen in these individuals.

\section{Thyroid Hormones}

Under basal conditions, the HPT axis is most active during the late evening hours, after which time, serum TSH levels decrease steadily to reach a nadir during the early morning hours (Ingbar 1985). Our results indicate that nocturnal TSH secretion, including its peak frequency, peak amplitude, and total area-under-the-curve, is normal in acutely abstinent alcoholic men. 
The TSH response to CRH plus TRH was also normal in our alcoholic patients. These results are at variance with most reports in the literature, including our own (Loosen et al. 1979, 1983, 1990), which demonstrated blunted TSH responses in some alcoholic men both during acute withdrawal and after prolonged abstinence (Loosen et al. 1992; Loosen 1988). It was possible that the combined administration of $\mathrm{CRH}$ and TRH may have produced false-positive TSH responses, but our study of 10 additional alcoholic men indicated that this was not the case. Differences in patient population characteristics may account for the divergent findings. Most of our patients suffered from severe, early onset, type II alcoholism (Cloninger 1987). A direct comparison of type I and type II alcoholics is necessary to support or reject this possibility. It is also possible that, because of early onset and disease severity, our patients suffered from liver disease. This is supported by gamma-glutamyltransferase elevations, which are reported to correlate with resistance to dexamethasone suppression. A recent review of the literature (Loosen et al. 1992) revealed that TSH blunting is more common in alcoholics without liver disease than in those with liver disease. Nine studies (Loosen et al. 1983; Dackis et al. 1984; Casacchia et al. 1985; Agner et al. 1986; Radouco-Thomas et al. 1984; Marchesi et al. 1989; Mueller et al. 1989; Willenbring et al. 1990; Garbutt et al. 1991) evaluated the TSH response to TRH in abstinent alcoholics without liver disease, and all but one (Agner et al. 1986) reported a blunted TSH response (Usually defined as a TSH increment of $<5$ or $<7 \mathrm{mU} / \mathrm{L}$ ) to TRH in some patients. In all, 163 patients received TRH, of whom 43 (26\%) showed a blunted TSH response. Six studies (van Thiel et al. 1979; Chopra et al. 1974; Agner et al. 1986; Monza et al. 1981; Hasselbalch et al. 1981; Green et al. 1977) evaluated abstinent alcoholics with liver disease, and all but one (Green et al. 1977) reported normal TSH responses. However, elevated basal serum TSH (van Thiel et al. 1979; Monza et al. 1981; Nomura et al. 1975; Green et al. 1977; Chopra et al. 1974) and reduced basal serum QT3 levels (van Thiel et al. 1979; Nomura et al. 1975; Green et al. 1977; Chopra et al. 1974; Israel et al. 1979; Hepner and Chopra 1979) were rather common. The reductions in serum QT3 concentrations appeared to derive from decreased conversion of T4 to T3, which was thought to be due to liver cell damage with loss of deiodinating capacity. Israel et al. (1979) and Israel and Orrego (1984) observed a strong inverse correlation between an index of liver disease and serum QT3 levels and reported that increasing QT3 levels during hospitalization were associated with clinical improvement. In our patients, in contrast, basal serum TSH and QT3 concentrations and TSH responses to TRH were all normal. More studies of abstinent alcoholics, especially ones that carefully control for the effects of liver status on thyroid function, will be required to explain the reason for the different findings of various investigators.

In summary, we observed no abnormalities in HPA or HPT function in abstinent alcoholic men other than a blunted ACTH but normal cortisol response to CRH. The blunted ACTH response does not appear to be the result of increased endogenous CRH activity, because all parameters of nocturnal ACTH pulsatility were normal in the alcoholics; rather, it may be due to a genetic defect or the effect of prolonged alcohol abuse or brief abstinence from chronic alcoholism.

\section{ACKNOWLEDGMENTS}

We thank Dr. Jean Rivier, The Salk Institute, La Jolla, CA, for the generous supply of synthetic ovine CRH: IgG Corporation, Nashville, TN, for the gift of anticorticotropin serum IgG-ACTH; Drs. Mark Applebaum and Lee Allard for statistical analysis of the data; and Wendell E. Nicholson, Bette Hawkins, Hope Cook and Virginia Farley for their expert technical assistance. This work was supported in part by VA Medical Research Funds, NIH Grant RR-00095 (to the General Clinical Research Center of Vanderbilt University), NIAAA Grant AA-07732, and NIMH Grant MH-45173.

\section{REFERENCES}

Adinoff B, Martin PR, Bone GH, Eckardt MJ, Roehrich L, George DT, Moss HB, Eskay R, Linnoila M, Gold PW (1990): Hypothalamic-pituitary-adrenal axis functioning and cerebrospinal fluid corticotropin releasing hormone and corticotropin levels in alcoholics after recent and longterm abstinence. Arch Gen Psychiatry 47:325-330

Agner T, Hagen C, Nyboe Andersen B, Hegedus L (1986): Pituitary-thyroid function and thyrotropin, prolactin and growth hormone responses to TRH in patients with chronic alcoholism. Acta Med Scand 220:57-62

Amsterdam JD, Maislin G, Winokur A, Berwish N, Kling M, Gold P (1988): The oCRH stimulation test before and after clinical recovery from depression. J Affect Dis 14:213-222

Begleiter H, Porjecz B, Lou CL (1981): Auditory brain stem potentials in chronic alcoholics. Science 211:1064-1066

Begleiter H, Porjecz B, Bihari B, Kissin B (1984): Event-related brain potentials in boys at risk for alcoholism. Science 225:1493-1495

Berman JD, Cook DM, Buchman M, Keith LD (1990): Diminished adrenocorticotropin response to insulin-induced hypoglycemia in nondepressed, actively drinking male alcoholics. J Clin Endocrinol Metab 71:712-717

Bertello P, Agrimonti F, Gurioli L, Frairia R, Fornardo D, Angeli A (1982): Circadian patterns of plasma cortisol and testosterone in chronic male alcoholics. Alcoholism 6:475-481

Casacchia M, Rossi A, Stratta P (1985): TRH test in recently abstinent alcoholics. Psychiatry Res 160:249-251

Chopra IJ, Soloman DH, Chopra U, Young RT, Chua Teco GN (1974): Alterations in circulating thyroid hormones 
and thyrotropin in hepatic cirrhosis: Evidence of euthryroidism despite subnormal serum triiodothyronine. J Clin Endocrinol Metab 39:501-511

Cloninger CR (1987): Neurogenetic adaptive mechanisms in alcoholism. Science 236:410-416

Cohen R, Bouquier D, Biot-Laporte S, Vermeulen E, Claustrat B, Cherpin MH, Cabrera P, Guidetti P, Ferry S, Bizollon CA, Sassolas G (1986): Pituitary stimulation by combined administration of four hypothalamic-releasing hormones in normal men and patients. JClin Endocrinol Metab 62:892-898

Dackis CA, Bailey J, Pottash AL, Stuckey RF, Extein IL, Gold MS (1984): Specificity of the DST and the TRH test for major depression in alcoholics. Am J Psychiatry 141:680683

Eckardt MJ, Ryback RS (1981): Neuropsychological concomitants of alcoholism. In Galanter M (ed), Currents in Alcoholism, Volume VIII. New York, Grune \& Stratton, pp 5-27

Evans DL, Golden RN (1987): The dexamethasone suppression test: A review. In Nemeroff CB, Loosen PT (eds), Handbook of Clinical Psychoneuroendocrinology. New York, Guilford Press, pp 313-335

Garbutt JC, Mayo JP, Gillette GM, LittleKY, Hicks RE, Mason GA, Prange AJ Jr (1991): Dose-response studies with thyrotropin-releasing hormone (TRH) in abstinent male alcoholics: Evidence for selective thyrotroph dysfunction? J Stud Alcohol 52:275-280

Gold PW, Gwirtsman HE, Avgerinos PC, Nieman LK, Galluci WT, Kaye WH, Jimerson D, Ebert M, Rittmaster R, Loriaux DL, Chrousos GP (1986a): Abnormal hypothalamic-pituitary-adrenal function in anorexia nervosa. $\mathrm{N}$ Engl J Med 314:1335-1342

Gold PW, Loriaux DL, Roy A, Kling MA, Calabrese Jr, Kellner CH, Nieman LK, Post RM, Pickar D, Gallucci W, Avgerinos P, Paul S, Oldfield EH, Cutler GB, Chrousos GP (1986b): Responses to corticotropin-releasing hormone in the hypercortisolism of depression and Cushing's disease. Pathophysiologic and diagnostic implications. N Engl J Med 314:1329-1335

Green JRB, Snitcher EJ, Mowat NAG, Ekins RP, Rees LH, Dawson AM (1977): Thyroid function and thyroid regulation in euthyroid men with chronic liver disease. Clin Endocrinol 7:453-461

Hamilton A (1960): A rating scale for depression. J Neurol Neurosurg Psychiatry 23:56-62

Hasselbalch HC, Bech K, Eskildsen PC (1981): Serum prolactin and thyrotropin responses of thyrotropin-releasing hormone in men with alcoholic cirrhosis. Acta Med Scand 209:37-40

Hepner GW, Chopra IJ (1979): Serum thyroid hormone levels in patients with liver disease. Arch Intern Med 139:1117-1120

Heuser I, von Bardeleben U, Boll E, Holsboer F (1988): Response of ACTH and cortisol to human corticotropinreleasing hormone after short-term abstention from alcohol abuse. Biol Psychiatry 24:316-321

Holl RW, Loos IJ, Hetzel WD, Heinze E, Fehm HL (1988): Combined pituitary stimulation test: Interactions of hypothalamic-releasing hormones in man. J Endocrinol Invest 111:219-223
Holsboer F, von Bardeleben U, Gerken A, Stalla GK, Mueller OA (1984): Blunted corticotropin and normal cortisol response to human CRF in depression. $\mathrm{N}$ Engl J Med 311:1127

Holsboer F, von Bardeleben U, Buller R, Heuser I, Steiger A (1987): Stimulation response to corticotropin-releasing hormone (CRH) in patients with depression, alcoholism and panic disorder. Hor Metab Res Suppl 16:80-88

Hotta M, Shibasaki T, Matsuda A, Imaki T, Demura H, Ling $\mathrm{N}$, Shimuze $\mathbf{N}$ (1986): The response of plasma adrenocorticotropin and cortisol to corticotropin-releasing hormone (CRH) and cerebrospinal fluid immunoreactive $\mathrm{CRH}$ in anorexia nervosa patients. J Clin Endocrinol Metab 62:319-324

Ingbar SH (1985): The thyroid gland. In Wilson JD, Foster DW (eds), Textbook of Endocrinology, 7th ed. Philadelphia, WB Saunders, pp 682-815

Iranmanesh A, Veldhuis JD, Johnson ML, Lizarralde G (1989): 24-hour pulsatile and circadian patterns of cortisol secretion in alcoholic men. J Androl 10:54-63

Israel Y, Walfish PG, Orrego H, Blake J, Kalant ZH (1979): Thyroid hormones in alcoholic liver disease. Gastroenterology 76:116-122

Israel Y, Orrego H (1984): Hypermetabolic state and hypoxic liver damage. Rec Dev Alcohol 2:119-133

Kathol RG, Jaeckle RS, Lopez JF, Meller WH (1989): Consistent reduction of ACTH responses to stimulation with $\mathrm{CRH}$, vasopressin and hypoglycemia in patients with major depression. Br J Psychiatr 155:468-478

Khan A, Ciraulo DA, Nelson WH, Becker JT, Nies A, Jaffe $\mathrm{JH}$ (1984): Dexamethasone suppression test in recently detoxified alcoholics: Clinical implications. J Clin Psychopharmacol 4:94-97

Lesch KP, Muller U, Rupprecht R, Kruse K, Schulte HM (1989): Endocrine responses to growth hormonereleasing hormone, thyrotropin-releasing hormone in depression. Acta Psychiatry Scand 79:597-602

Little G (1981): The adrenals. In Williams RH (ed), Textbook of Endocrinology. Philadelphia, WB Saunders, pp 249-292

Loosen PT, Prange AJ Jr, Wilson IC (1979): TRH (Protirelin) in depressed alcoholic men: Behavioral changes and endocrine responses. Arch Gen Psychiatry 36:540-547

Loosen PT, Wilson IC, Dew BW, Tipermas A (1983): Thyrotropin-releasing hormone (TRH) in abstinent alcoholic men. Am J Psychiatry 140:1145-1149

Loosen PT (1988): Thyroid function in affective disorders and alcoholism. Endocrinol Metab Clin North Am 17:55-82

Loosen PT, Dew Bess W, Prange AJ Jr (1990): Long-term predictors of outcome in abstinent alcoholic men. Am J Psychiatry 147:1662-1666

Loosen PT, Chambliss B, Pavlou SN, Orth DN (1991): Adrenal function in abstinent alcoholic men. Prog Neuropsychopharmacol Biol Psychiatry 15:771-780

Loosen PT, Sells S, Geracioti TD, Garbutt JC (1992): Thyroid hormones and alcoholism. In Watson RR (ed), Drug and Alcohol Abuse Reviews, Vol. 3. Clifton, NJ, Humana Press, pp 283-306

Lundberg GD, Iverson C, Radulescu G (1986): Now read this: The SI units are here. JAMA 255:2329-2339 
Marchesi C, Campanini T, Govi A, Tampieri E, Gnudi A, Chiodera P, Coiro V (1989): Abnormal thyroid stimulating hormone, prolactin, and growth hormone responses to thyrotropin releasing hormone in abstinent alcoholic men with cerebral atrophy. Psychiatry Res 28:89-96

Marks V, Wright JW (1977): Endocrinology and metabolic effects of alcohol. Proc Roy Soc Med 70:337-349

Mendelson JM, Stein S (1966): Serum cortisol levels in alcoholic and nonalcoholic subjects during experimentally induced ethanol intoxication. Psychosom Med 28:616-626

Monza GC, Lampertico M, Ferrari A, Tarolo GL, Picozzi R, Camerone G, Neri V, Broggi A (1981): Prolactin and thyrotropin secretion in alcoholic liver cirrhosis: Study of the variations induced by TRH, metoclopramide and cimetidine. J Nucl Med All Sci 25:71-78

Mortola JF, Liu JH, Gillin JC, Rasmussen DD, Yen SS (1987): Pulsatile rhythms of adrenocorticotropin (ACTH) and cortisol in women with endogenous depression: Evidence for increased ACTH pulse frequency. J Clin Endocrinol Metab 65:962-968

Mueller N, Hoehe M, Klein HE, Nieberle G, Kapfhammer HP, May F, Mueller OA, Fichter M (1989): Endocrinological studies in alcoholics during withdrawal and after abstinence. Psychoneuroendocrinology 14:113-123

Nomura S, Pittman CS, Chambers JB, Buck MW, Shimizu $\mathrm{T}$ (1975): Reduced peripheral conversion of thyroxine to trioodothyronine in patients with hepatic cirrhosis. J Clin Invest 56:643-652

Prinz PN, Roehrs TA, Vitaliano PP, Linnoila M, Weitzman E (1980): Effect of alcohol on sleep and nighttime plasma growth hormone and cortisol concentrations. J Clin Endocrinol Metab 51:759-764

Radouco-Thomas S, Garcin F, Murphy MRV, Faure N, Lemay A, Forest JC, Radouco-Thomas C (1984): Biological markers in major psychosis and alcoholism: Phenotypic and genotypic markers. J Psychiatry Res 18:513-539

Rees LH, Besser GM, Jeffcoate WJ, Goldie EJ, Marks V, et al (1977): Alcoholic pseudo-Cushing's. Lancet 1:726

Risher-Flowers D, Adinoff B, Ravitz B, Bone GHA, Martin PR, Nutt D, Linnoila M (1988): Circadian rhythms of cortisol during alcohol withdrawal. Adv Alcohol Subst Abuse 7:37-41

Rosman PM, Farag A, Benn R, Tito J, Mishik A, Wallace EZ (1982): Modulation of pituitary-adrenocortical function: Decreased secretory episodes and blunted circadian rhythmicity in patients with alcoholic liver disease. J Clin Endocrinol Metab 55:709-717

Roy Byrne PP, Uhde TW, Rubinow DR, Post RM (1986): Reduced TSH and prolactin responses to TRH in patients with panic disorder. Am J Psychiatry 143:503-507

Santen RD, Bardin CW (1973): Episodic LH secretion in man. $\mathrm{J}$ Clin Invest 52:2617-2624

Schopohl J, Losa M, Koenig A, Mueller OA, Stalla GK, von Werder K (1986): Combined pituitary function test with four hypothalamic-releasing hormones. Klin Wschr 64:314-318

Schuckit MA, Gold E, Risch SC (1987a): Plasma cortisol levels following ethanol in sons of alcoholics and controls. Arch Gen Psychiatry 44:942-945

Schuckit MA, Gold E, Risch SC (1987b): Serum prolactin lev- els in sons of alcoholics and control subjects. Am J Psychiatry 144:854-859

Schuckit MA, Risch SC, Gold EO (1988): Alcohol consumption, ACTH level, and family history of alcoholism. Am J Psychiatry 145:1391-1395

Selzer ML (1971): The Michigan alcoholism screening test: The quest for a new diagnostic instrument. Am J Pyschiatry 127:1653-1658

Sheldon WR, deBold CR, Evans WS, deCherney GS, Jackson RV, Island DP, Thorner MO (1985): Rapid sequential intravenous administration of four hypothalamic releasing hormones as a combined anterior pituitary function test in normal subjects. J Clin Endocrinol Metab 60:623-630

Smals AG, Kloppenborg PW, Njo KT, Knoben JM, Ruland CM (1976): Alcohol-induced cushingoid syndrome. Br Med J 2:1298

Smith MA, Davidson J, Ritchie JC, Kudler H, Lipper S, Chappell P, Meneroff CB (1989): The corticotropin-releasing hormone test in patients with posttraumatic stress disorder. Biol Psychiatry 26:349-355

Spitzer RL, Endicott J, Robins E (1978): Research diagnostic criteria: Rationale and reliability. Arch Gen Psychiatry 35:773-783

Swartz CM, Dunner FJ (1984): Recent alcohol abstinence and the dexamethasone suppression test. Am J Psychiatry 141:1643-1644 (Letter)

Targum SD (1984): Persistent neuroendocrine dysregulation in major depressive disorder: A marker for early relapse. Biol Psychiatry 19:305-318

Tarter RE, Hegedus AM, Goldstein G, Shelly C, Alterman AI (1984): Adolescent sons of alcoholics: Neuropsychological and personality characteristics. Alcohol Clin Exp Res 8:216-222

Tarter RE, Edwards KL (1985): Neuropsychology of alcoholism. In Tarter RE, van Thiel DH (eds), Alcohol and the Brain: Chronic Effects. New York, Plenum Press, pp 217-242

Urban RJ, Johnson ML, Veldhuis JD (1989): In vivo biological validation and biophysical modeling of the sensitivity and positive accuracy of endocrine peak detection. I. The LH pulse signal. J Clin Endocrinol Metab 124:2541-2547

Valimaki M, Pelkonen R, Harkonen M, Ylikahri R (1984):Hormonal changes in noncirrhotic male alcoholics during ethanol withdrawal. Alcohol Alcohol 19:235-242

van Thiel DH, Smith WJ, Wright C, Abuid J (1979): Elevated basal and abnormal TRH-induced TSH secretion in chronic alcoholic men with liver disease. Alcohol Clin Exp Res 3:302-308

van Thiel DH, Gavaler JS, Cobb CF (1983): Pseudo-Cushing's Syndrome and alcohol abuse. In Ethanol Tolerance and Dependence: Endocrinological Aspects. Rockville, MD. National Institute on Alcohol Abuse and Alcoholism Research Monograph 13, pp 117-126

Veldhuis J, Evans W, Rogol A, Drake C, Thorner MD, Merriam G, Johnson $M$ (1984): Intensified rates of venous sampling unmask the presence of spontaneous, high frequency pulsations of LH in man. J Clin Endocrinol Metab 59:96-102

von Bardeleben U, Stalla GK, Muller OA, Holsboer F (1988): 
Blunting of ACTH response to human CRH in depressed patients is avoided by metyrapone pretreatment. Biol Psychiatry 24:782-786

von Bardeleben U, Heuser I, Holsboer F (1989): Human CRH stimulation response during acute withdrawal and after medium-term abstention from alcohol abuse. Psychoneuroendocrinology 14:441-449
Willenbring ML, Anton RF, Spring WD Jr, Shafer RB, Dorus W (1990): Thyrotropin and prolactin response to thyrotropin-releasing hormone in depressed and nondepressed alcoholic men. Biol Psychiatry 27:31-38

Winer B J (1976): Statistical Principles in Experimental Design. New York, McGraw-Hill 